\title{
土木工程施工中的材料选择及质量控制措施
}

\author{
韦程皓 \\ 广西建工集团第五建筑工程有限责任公司
}

DOI:10.32629/btr.v2i12.2724

[摘 要] 随着我国的生产力的快速发展, 也为了满足人民对现阶段的生活、工作环境的提高, 我国的土木建筑行业也在飞速的发展, 但随着飞速 发展的而来的也是诸多问题。施工中的材料选择和质量控制措施尤为关键。本文对土木工程施工中材料选择和质量控制措施进行讨论, 进而加 以改进。

[关键词] 土木工程; 施工材料; 质量控制

土木工程施工, 所有的项目都是大规模的, 周期性很长的, 而且投资的 金额很大的。最主要是项目管理环节难, 涉及到的内容难度较大。施工的 质量直接影响整个建筑的后期建设情况。所以材料的选择和质量控制就显 得格外重要。所以土木工程企业一定要把握好成本, 做好材料管理工作, 并在此管理的基础上, 完善质量控制。才能保证整个施工过程中整体的可 靠与稳定 ${ }^{[1]}$ 。

\section{1 土木工程施工过程中材料选择和管理的重要性}

土木工程的材料选择和管理是整个施工中的最重要环节, 它是保证后 期施工管理能否正常进行的重中之重。施工材料的投资占整个工程的6成 到8成之间。高额的资金投入也让材料的选择管理成为了焦点。使用高质 量的材料施工才能保证土木建筑的工程项目质量的高质量。材料的好坏直 接影响施工的进度。提高施工材料的的选择和管理力度, 合理运用管理手 段, 会让工程事半功倍, 节省了时间还为企业带来良好的效益 ${ }^{[2]}$ 。

\section{2 我国现阶段土木工程材料选择和质控方面存在的问题分析}

2. 1 缺少相关的材料选择管理人才

根据调查发现, 现阶段一些土木工程的企业施工单位的施工质量差强 人意甚至堪忧的主要原因是因为缺少专业的管理人员,才导致了一些工程 问题无法及时的被发现，从而导致了施工项目的质量无法达到预期的涉及 要求。施工中, 施工单位会指派很多的相关人员去选择, 但这些人员的相关 的水平有限, 导致了材料与施工要求存在偏差, 施工质量无法有效地提升。

2.2 材料选择中需要注意的问题

随着人民对美好生活的要求的提高, 施工材料的选择运用日益成为人 们关注的焦点。在我国, 由于地理位置的差异, 不同的地理位置选择的施工 也有所差别。要根据具体的位置进行侦察测量, 指派相关专业人士进行施 工材料的选择。但现在企业因为缺乏相关知识, 导致选购材料时出现了各 样的问题, 从而影响施工进度, 并且为后面的施工留下隐患 ${ }^{[3]}$ 。

2. 3缺乏相关管理办法和制度

现在的施工单位只是注重员工的个人能力, 对于责任意识没有进行有 限的培养, 部分企业对材料管理轻视, 没有指定完整的材料管理的制度, 从 而导致了后期的隐患的存在。施工企业应制定相对应的制度, 对材料进行 明确的管理, 并对员工进行相关责任教育, 以保证企业的长久发展性。

\section{3 土木工程的施工当中材料的选择和质量的控制措施}

3. 1 科学的进行施工材料的选择和增强对施工材料的检测

科学的发展的进步推动了土木行业的进一步发展, 进而产生很多新型 的材料。相对于传统的材料来说, 新型材料改变了传统材料的体积过大, 运输困难的问题。例如合金材料、塑钢材料等。为了保证整个工程的质量,
必须要重视建筑材料的选择。选择质量符合工程要求的材料,制定材料选 择规则, 并对其进行约束管理。对生产商进行资质审核, 分析其销售、反馈 的治疗, 从而保证材料的质量。只有保证了材料的良好, 才能为后期的工程 施工提供保障 ${ }^{[4]}$ 。

3.2 强化工人素质管理力度并加强信息建设

在施工单位中, 员工是整个单位主要构成, 员工的基本素养是整个企 业能否继续发展下去的直接因素, 对员工进行定期的培养并考核确保对基 本知识的学习。对于材料的等级, 传统的材料登记管理数据应为其量大导 致在采用报表方式记录的数据容易发生错误。现代信息的建设, 可以让工 人们利用信息网络平台记录, 以保证工程材料的信息得到第一时间的运用, 进而有效降低工程建设的成本。

3. 3加大监管投入力度, 完善健全管理的投入机制

很多施工的单位会将自己的人员进行工作划分, 但工作人员职责划分 不明确, 甚至有的人员为了谋取自身利益, 使得工程质量大大缩水。造成工 程后期隐患。针对这种情况, 施工单位需要加大监管力度, 从思想上改变, 提升本门人员的基本素养, 建立完整的责任制度, 使得岗位上的每一个人 都了解明确自己身上的责任。坚决杜绝岗位上的人使用不正当的关系获得 职位。保证职位的公平, 公正, 公开。并严格按照《安全生产法》的规定落 实管理, 最大限度解决施工安全的相关问题。构架完善的管理投入, 做到专 款专用。确保施工安全, 保证施工的效益。

\section{4 结束语}

在未来, 我国会继续扩大土木工程的建设, 为了满足其发展的空间, 建 筑企业必须提高发展速度。而随着现在的发展趋势, 建筑也在逐渐的向高 层发展, 这就对建筑的施工质量加以重视。在材料上要选择质量更好地材 料, 做好材料的质量监控管理, 在第一时间发现问题并解决, 做到对使用项 目质量提升最大话, 进而提升建筑质量。

[参考文献]

[1]金康,赵翔.土木工程施工中的材料选择及质量控制措施[J].农家 参谋,2018,(05):192.

[2]吕志江.土木工程施工中的材料选择及质量控制措施[J].成功: 中 下,2018,(15):86-86.

[3]章燕妮.浅谈土木工程施工中的材料选择及质量控制措施[J].江西 建材,2016,186(09):75+77.

[4]郭霖,陈建利,周建权.土木工程施工中的材料选择及质量控制措施 分析[J].建筑工程技术与设计,2017,(8):65. 